\title{
Vaginal delivery versus elective cesarean section and disease incidence in children aged up to 2 years
}

Parto eutócico versus cesariana eletiva e a incidência de patologias na criança até aos 2 anos Parto eutócico frente a cesárea electiva e incidencia de patologías en el niño hasta los 2 años

Sílvia Manuela Leite Rodrigues*; Paulo Manuel Marques Silva**

\begin{abstract}
Background: Cesarean section is often associated with an increased disease incidence in children. Given the controversial indications for cesarean sections, the significant increase in cesarean section rates may put children at risk. Objective: To investigate the existence of differences in disease incidence up to the age of two between children who were born by vaginal delivery and those born by elective cesarean section.

Methodology: Quantitative study, through multivariate analysis, using the binary logistic regression in SPSS, version 18.0 .

Results: No statistically significant differences were found between children born by elective cesarean section and those born by vaginal delivery regarding the incidence of transient tachypnea and hypoglycemia immediately after birth, and the incidence of allergies, gastroenteritis, tonsillitis, urinary tract infection, and otitis until the age of 2 .

Conclusion: No statistically significant differences were found in the incidence of diseases until the age of two between children born by elective cesarean section and by vaginal delivery.
\end{abstract}

Keywords: diseases; childbirth; cesarean section; child

\section{Resumo}

Enquadramento: A cesariana é associada ao aumento da incidência de patologias na criança. Atendendo que existem indicaçóes para cesariana controversas, o aumento exponencial da taxa de cesarianas pode colocar as crianças em risco.

Objetivo: Verificar se existem diferenças entre os nascidos de parto eutócico e os nascidos de cesariana eletiva na incidência de patologias até aos 2 anos.

Metodologia: Quantitativa, através da análise multivariada com aplicação da regressão logística binária no software SPSS, 18.0.

Resultados: Os nascidos de cesariana eletiva náo apresentam diferenças significativas na incidência de taquipneia transitória e hipoglicemia após o nascimento e na incidência de alergias, gastroenterite, amigdalite, infeção urinária e otite até aos 2 anos em comparação com os nascidos por parto eutócico.

Conclusáo: Os nascidos de cesariana eletiva não apresentam diferenças estatisticamente significativas quanto à incidência de patologias até aos 2 anos comparativamente com os nascidos de parto eutócico.

Palavras-chave: doenças; parto; cesariana; criança

*Ph.D., Clinical nurse specialist in Maternal and Obstetric Health, Hospital of Braga, 4710-243, Braga, Portugal [silvialeiterodrigues@gmail.com]. Contribution to the article: literature search, data collection, statistical treatment and evaluation, analysis and discussion. Address for correspondence: Avenida D. João II $\mathrm{n}^{\circ} 48,3$ direito, 4710-243, São Victor, Braga, Portugal.

**MSc., RN, Hospital of Braga, 4710-243, Braga, Portugal [paulommsilva@gmail.com]. Contribution to the article: statistical treatment and evaluation, analysis and discussion, article writing.

\section{Resumen}

Marco contextual: La cesárea se asocia a una mayor incidencia de patologías en el niño. Dado que existen indicaciones controvertidas para la cesárea, el aumento exponencial de la tasa de cesáreas puede poner a los niños en riesgo.

Objetivo: Comprobar si existen diferencias entre los nacidos por parto eutócico y los nacidos por cesárea electiva en la incidencia de patologías hasta los 2 ańos. Metodología: Cuantitativa, a través del análisis multivariado con aplicación de la regresión logística binaria en el software SPSS, 18.0.

Resultados: Los nacidos por cesárea electiva no presentan diferencias significativas en la incidencia de taquipnea transitoria e hipoglucemia después del nacimiento ni incidencia de alergias, gastroenteritis, amigdalitis, infección urinaria y otitis hasta los 2 años en comparación con los nacidos por parto eutócico.

Conclusión: Los nacidos por cesárea electiva no presentan diferencias estadísticamente significativas en cuanto a la incidencia de patologías hasta los 2 años en comparación con los nacidos por parto eutócico.

Palabras clave: enfermedades; parto; cesárea; ninố 


\section{Introduction}

In recent decades, the phenomenon of increasing cesarean section rates has reached world levels. In its activity report, the Northern Regional Health Administration (Administração Regional de Saúde do Norte, 2011) revealed that the cesarean section rate was of $30 \%$ in 2011 in Northern Portugal, but it was in 2010 that the rate of $36 \%$ was reached. For this reason, Portugal is among the European countries with high cesarean section rates. According to the World Health Organization (2015), a cesarean section rate above $10-15 \%$ does not reduce maternal or neonatal mortality rates, so there is no justification for rates higher than $15 \%$. Therefore, there is great controversy over some clinical indications for cesarean section.

Cesarean section is associated with several conditions in the literature: Roduit, Scholtens, and Jongste (2009) associate it with an increased incidence of asthma; Pistiner, Gold, and Abdulkerim (2008) associate it with atopy; Hyde and Moodi (2012) associate it with type 1 diabetes; Decker, Hornef, and Stockinger (2011) associate it with inflammatory bowel disease; and Wang et al. (2013) associate it with childhood obesity. In this way, cesarean sections with controversial indication can be considered unnecessary and a contributing factor to increased child morbidity rates.

The objective of this study is to investigate the existence of differences in disease incidence until the age of two between children born by vaginal delivery and those born by elective cesarean.

\section{Background}

A cesarean section can be the ideal delivery method in certain situations, but it can be unnecessary if there is a controversial clinical indication. Campos (2008) considers suspected fetopelvic disproportion (FPD) to be a controversial clinical indication since it is based on a subjective clinical evaluation that has a low predictive capacity of the success of vaginal delivery.

Based on the theory that infants develop their intestinal flora while in contact with the mother's vaginal and fecal fluids, microbial exposure during the passage through the birth canal may influence the infant's immune system. According to Roduit et al. (2009), cesarean section tends to increase the risk of asthma when compared to vaginal delivery. Huurre, Kalliomaki, and Rautava (2008) argue that the early exposure to microbes and infections protects children against the development of asthma and other allergic diseases. Ngoc et al. (2006) found that infants born by cesarean section had higher interleukin (IL)13 and interferon (IFN)-gamma levels than those who were born by vaginal delivery, thus the increased expression of these cytokines is associated with the development of asthma and allergies. In addition, Salam et al. (2006) argued that cesarean section increases the risk of atopic disease in childhood, in a manner similar to the risk of the presence of family history of asthma or allergies.

Hyde and Moodi (2012) found an association between cesarean section and the onset of type 1 diabetes, and Decker et al. (2011) associated it with inflammatory bowel disease. Wang et al. (2013) reported that cesarean sections are associated with increased risk of overweight and obesity at the age of 6, although this association is different according to gender.

\section{Hypothesis}

H1: There is a higher incidence of allergies among children born by cesarean section than among those born by vaginal delivery.

$\mathrm{H} 2$ : There is a higher incidence of gastroenteritis among children born by cesarean section than among those born by vaginal delivery.

H3: There is a higher incidence of urinary tract infection among children born by cesarean section than among those born by vaginal delivery.

H4: There is a higher incidence of tonsillitis among children born by cesarean section than among those born by vaginal delivery.

H5: There is a higher incidence of otitis among children born by cesarean section than among those born by vaginal delivery. H6: There is a higher incidence of hypoglycemia among children born by cesarean section 
than among those born by vaginal delivery. H7: There is a higher incidence of transient tachypnea after birth among children born by cesarean section than among those born by vaginal delivery.

\section{Methodology}

The sample consisted of 400 mother-child dyads. More specifically, infants born in 2011 at the Hospital of Braga, by vaginal delivery or elective cesarean section, after a gestational period equal to or higher than 37 weeks, weighing more than $2.500 \mathrm{Kg}$, single birth. Cases of emergency cesarean section, multiple birth, chromosomal abnormality, or congenital malformation were excluded.

Data started to be collected through the analysis of the records of new mothers and their children born in 2011 at the Hospital of Braga. The authorization to conduct the study had been previously requested and obtained from the hospital, as well as the favorable opinion of the ethics committee to access the records.

In a first phase, data were collected from the mothers and infants' clinical records. The following data were collected from the mothers' records: body mass index, age, academic qualifications, occupation, marital status, smoking habits, folic acid intake before and during pregnancy, pregnancy surveillance, participation in childbirth preparation classes, and diseases during pregnancy. Data were also collected about the mothers' obstetric history such as parity (upon hospital admission), previous method of delivery (vaginal delivery or elective/emergency cesarean section), and characteristics of the current delivery, namely the type of delivery, total duration of ruptured membranes, presence of Group B Streptococcus (Streptococcus agalactiae), and, in cases of cesarean section, the indication for cesarean section.

In addition, the following data were collected from the infants' records: gestational age, birth weight, 5-minute Apgar score, and immediate hospitalization in the neonatal intensive care unit, as well as the development of diseases, namely hypoglycemia and transient tachypnea immediately after birth and gastro- enteritis, urinary infection, otitis, tonsillitis, and allergies until the age of 2 . The data on disease incidence were collected from the infants' clinical records whenever they were diagnosed and treated at the hospital where the study was conducted.

In a second phase, data were collected using structured interviews with closed-ended questions. A total of 400 interviews were conducted with mothers when the children were two years old. Each interview was conducted on two occasions separated by a 2 week interval. Mothers were asked about breastfeeding, namely about the duration and exclusivity of breastfeeding. The interviews also included questions about the development of diseases up to the age of 2. Finally, mothers were asked if children attended a nursery or a nanny or if they were under the care of the parents themselves. In this way, data on the incidence of diseases among children up to 2 years old were collected by consulting the children's clinical files and interviewing the mothers.

Multivariate analysis was performed using binary logistic regression analysis in SPSS, version 18.0. Seven regressions were performed, and the dependent variable in each regression (allergies, gastroenteritis, otitis, urinary infection, tonsillitis, hypoglycemia, and transient tachypnea) was adjusted to potentially confounding independent variables: mothers' characteristics, namely age, academic qualifications, scientific and intellectual or non-scientific profession (intermediate level technicians and professionals, administrative staff, service and sales workers, factory workers and operators, non-skilled workers, homemakers, and unemployed), marital status, body mass index, childbirth preparation classes, planned pregnancy, parity (upon hospital admission), folic acid intake before pregnancy and during pregnancy, smoking habits during pregnancy, gestational hypertension, gestational diabetes, pre-eclampsia, and previous method of delivery (vaginal delivery and emergency/elective cesarean section); children's characteristics, namely gestational age, gender, 5-minute Apgar score, birth weight, immediate hospitalization in the neonatal intensive care unit, attending a nursery or a nanny, exclusive breastfeeding during the infant's first six months of life, and duration of breastfeeding until the age of 2 ; and, 
finally, the characteristics of the delivery, namely the total duration of ruptured membranes, the presence of Group B Streptococcus, and delivery method (vaginal delivery or elective cesarean section). Given the multifactorial nature of the problem, all independent variables were used in each regression to assess the impact of other variables on the model.

\section{Presentation of the sample}

The characteristics of the sample, namely the characteristics of the mothers, the delivery, and the children born by vaginal delivery and cesarean section, are described in Table 1.

\section{Table 1}

Characteristics of the mothers, children, and delivery

\begin{tabular}{|c|c|c|c|c|c|c|c|c|c|c|c|c|}
\hline \multirow[b]{2}{*}{ Variables } & \multicolumn{2}{|c|}{$\begin{array}{l}\text { Vaginal } \\
\text { Delivery }\end{array}$} & \multicolumn{2}{|c|}{$\begin{array}{c}\text { Elective } \\
\text { Cesarean } \\
\text { Section }\end{array}$} & \multicolumn{2}{|c|}{$\begin{array}{l}\text { Vaginal } \\
\text { Delivery }\end{array}$} & \multicolumn{2}{|c|}{$\begin{array}{c}\text { Elective } \\
\text { Cesarean } \\
\text { Section }\end{array}$} & \multicolumn{2}{|c|}{$\begin{array}{l}\text { Vaginal } \\
\text { Delivery }\end{array}$} & \multicolumn{2}{|c|}{$\begin{array}{c}\text { Elective } \\
\text { Cesarean } \\
\text { Section }\end{array}$} \\
\hline & $N$ & $\%$ & $N$ & $\%$ & $N$ & $\%$ & $N$ & $\%$ & $N$ & $\%$ & $N$ & $\%$ \\
\hline \multicolumn{13}{|l|}{ Mothers' characteristics } \\
\hline \multicolumn{13}{|l|}{ Age } \\
\hline$\leq 25$ years & 47 & 21 & 15 & 8 & & & & & & & & \\
\hline$>25$ years & 174 & 79 & 164 & 92 & & & & & & & & \\
\hline \multicolumn{13}{|l|}{ Academic qualifications } \\
\hline Up to $12^{\text {th }}$ grade & 176 & 80 & 145 & 81 & & & & & & & & \\
\hline Bachelor's degree & 44 & 20 & 34 & 19 & & & & & & & & \\
\hline \multicolumn{13}{|l|}{ Profession } \\
\hline Non-scientific & 188 & 85 & 151 & 84 & & & & & & & & \\
\hline $\begin{array}{l}\text { Scientific and } \\
\text { intellectual }\end{array}$ & 33 & 15 & 28 & 16 & & & & & & & & \\
\hline \multicolumn{13}{|l|}{ Marital status } \\
\hline Married & 202 & 91 & 173 & 97 & & & & & & & & \\
\hline Unmarried & 15 & 9 & 5 & 3 & & & & & & & & \\
\hline \multicolumn{13}{|l|}{ Body mass index (BMI) } \\
\hline $\begin{array}{l}\text { Normal weight } \\
(\geq 35 \mathrm{~kg} / \mathrm{m} 2)\end{array}$ & 37 & 17 & 17 & 9 & & & & & & & & \\
\hline $\begin{array}{l}\text { Overweight }(>18 \mathrm{~kg} / \mathrm{m} 2 \\
\text { and }<35 \mathrm{~kg} / \mathrm{m} 2)\end{array}$ & 181 & 83 & 159 & 91 & & & & & & & & \\
\hline \multicolumn{13}{|l|}{ Childbirth preparation classes } \\
\hline Yes & 89 & 38 & 50 & 28 & & & & & & & & \\
\hline No & 132 & 62 & 129 & 72 & & & & & & & & \\
\hline \multicolumn{13}{|l|}{ Planned pregnancy } \\
\hline Yes & 183 & 83 & 145 & 81 & & & & & & & & \\
\hline No & 38 & 17 & 34 & 19 & & & & & & & & \\
\hline \multicolumn{13}{|l|}{ Parity (upon admission) } \\
\hline Nulliparous & 108 & 49 & 41 & 23 & & & & & & & & \\
\hline Multiparous & 113 & 51 & 138 & 77 & & & & & & & & \\
\hline \multicolumn{13}{|l|}{$\begin{array}{l}\text { Folic acid intake before } \\
\text { pregnancy }\end{array}$} \\
\hline Yes & 141 & 64 & 71 & 40 & & & & & & & & \\
\hline No & 80 & 36 & 108 & 80 & & & & & & & & \\
\hline \multicolumn{13}{|l|}{$\begin{array}{l}\text { Folic acid intake during } \\
\text { pregnancy }\end{array}$} \\
\hline Yes & 207 & 94 & 176 & 98 & & & & & & & & \\
\hline No & 14 & 6 & 3 & 2 & & & & & & & & \\
\hline \multicolumn{13}{|l|}{$\begin{array}{l}\text { Smoking habits during } \\
\text { pregnancy }\end{array}$} \\
\hline Yes & 29 & 13 & 13 & 7 & & & & & & & & \\
\hline No & 191 & 87 & 166 & 93 & & & & & & & & \\
\hline
\end{tabular}




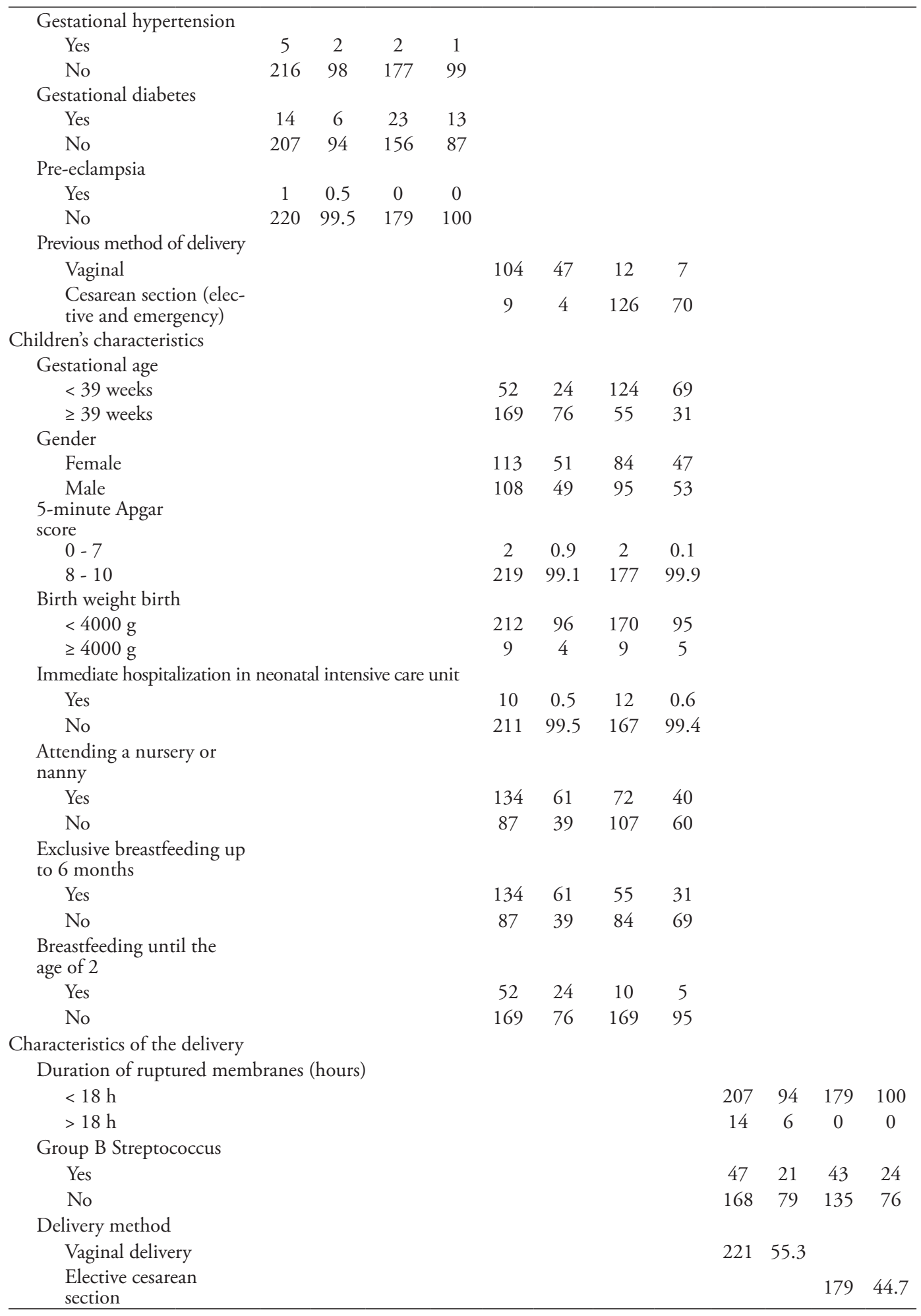

\section{Results}

Table 2 shows that the incidence of allergies, gastroenteritis, otitis, urinary infections, hypoglycemia, and transient tachypnea is lower among children born by vaginal delivery than among those born by elective cesarean section. 
Table 2

Incidence of allergies, gastroenteritis, otitis, urinary infections, tonsillitis, hypoglycemia, and transient tachypnea in children born by vaginal delivery and those born by elective cesarean section

\begin{tabular}{lccccc}
\hline & & \multicolumn{2}{c}{ Vaginal delivery } & \multicolumn{2}{c}{ Elective cesarean section } \\
\cline { 3 - 6 } & & $N$ & $\%$ & $N$ & $\%$ \\
\hline \multirow{2}{*}{ Allergies } & Yes & 2 & 0.9 & 12 & 7 \\
& No & 219 & 99.1 & 167 & 93 \\
Gastroenteritis & Yes & 4 & 2 & 10 & 6 \\
\multirow{2}{*}{ Otitis } & No & 217 & 98 & 169 & 94 \\
\multirow{3}{*}{ Urinary infection } & Yes & 25 & 13 & 26 & 15 \\
& No & 196 & 87 & 153 & 85 \\
Tonsillitis & Yes & 2 & 0.9 & 6 & 3 \\
\multirow{2}{*}{ Hypoglycemia } & No & 219 & 99.1 & 173 & 97 \\
& Yes & 13 & 6 & 157 & 88 \\
Transient tachypnea & No & 208 & 94 & 26 & 12 \\
& Yes & 0 & 0 & 4 & 2 \\
& No & 221 & 100 & 175 & 98 \\
& Yes & 3 & 2.3 & 10 & 6 \\
\end{tabular}

Odds ratios (OR) were calculated for each disease using binary logistic regression. The characteristics of mothers, children, and the delivery method were introduced into the model. The model was adjusted for potentially confounding variables.

No statistically significant differences were found in the incidence of gastroenteritis, urinary infection, tonsillitis, otitis, and allergies up to the age of two between children who were born by elective cesarean section or by vaginal delivery. No differences were also found in the incidence of hypoglycemia and transient tachypnea immediately after birth, as can be seen in Table 3 .

\section{Table 3}

Results of the incidence of allergies, gastroenteritis, urinary infection, tonsillitis, and otitis until the age of 2, and of hypoglycemia and transient tachypnea immediately after birth in children born by elective cesarean section, when compared to those born by vaginal delivery

\begin{tabular}{|c|c|c|c|}
\hline & $O R$ & 95\% Confidence Interval & $p$ \\
\hline \multicolumn{4}{|l|}{ Incidence of allergies } \\
\hline Elective cesarean section & 2.316 & \multirow{2}{*}{$0.773 ; 3.859$} & \multirow{2}{*}{0.333} \\
\hline Vaginal delivery & 0 & & \\
\hline \multicolumn{4}{|l|}{ Incidence of gastroenteritis } \\
\hline Vaginal delivery & 1.162 & \multirow{2}{*}{$0.391 ; 2.715$} & \multirow{2}{*}{0.142} \\
\hline Elective cesarean section & 0 & & \\
\hline \multicolumn{4}{|l|}{ Incidence of urinary infection } \\
\hline Vaginal delivery & 1.346 & \multirow{2}{*}{$0.267 ; 2.959$} & \multirow{2}{*}{0.102} \\
\hline Elective cesarean section & 0 & & \\
\hline \multicolumn{4}{|l|}{ Incidence of tonsillitis } \\
\hline Elective cesarean section & 0.242 & \multirow{2}{*}{$-0.636 ; 1.121$} & \multirow{2}{*}{0.589} \\
\hline Vaginal delivery & 0 & & \\
\hline \multicolumn{4}{|l|}{ Incidence of otitis } \\
\hline Elective cesarean section & 0.028 & \multirow{2}{*}{$-0.037 ; 1.094$} & \multirow{2}{*}{0.400} \\
\hline Vaginal delivery & 0 & & \\
\hline \multicolumn{4}{|l|}{ Incidence of hypoglycemia } \\
\hline Elective cesarean section & 1.022 & \multirow{2}{*}{$0.421 ; 1.604$} & \multirow{2}{*}{0.997} \\
\hline Vaginal delivery & 0 & & \\
\hline \multicolumn{4}{|c|}{ Incidence of transient tachypnea } \\
\hline Elective cesarean section & 1.051 & \multirow{2}{*}{$0.580 ; 1.660$} & \multirow{2}{*}{0.284} \\
\hline Vaginal delivery & 0 & & \\
\hline
\end{tabular}




\section{Discussion}

The hygiene hypothesis argues that an inadequate early-life exposure to bacteria contributes to the increased risk of developing immune diseases (Strachan, 1989). The first bacteria to which infants are exposed may alter the development of their immune system (Neu \& Rushing, 2011). According to Cho and Norman (2013), when compared to vaginal delivery, a cesarean section may affect the development of the immune system by changing the bacterial colonization of the intestinal tract, triggering a maladaptive stress response, and altering the epigenetic regulation of the gene expression through deoxyribonucleic acid (DNA) methylation on cytosine-phosphate-guanine (CpG) dinucleotides. Martino and Prescott (2010) believe that the early DNA methylation may compromise the immune system since it may inhibit the regulation of type 1 and type 2 T-helper cell (Th1/Th2) balance.

According to Kaplan, Shi, and Walker (2011), the human microbiome / gut microbiome regulates neonates' immune system by promoting T-cell development and Th1/Th2 balance. In addition, Huurre et al. (2008) report that, at the age of 12 months, the number of immunoglobulin-secreting cells (Ig-A and Ig-G) was higher in children born by cesarean section than in those born by vaginal delivery.

With regard to the development of diseases, the results of this study are somehow homogenous in their incidence. Thus, similarly to the study by Karpa et al. (2012), no significant differences were found between the delivery method and the incidence of allergies in children born by elective cesarean section when compared to those born by vaginal delivery $(O R$ $=2.316 ; 95 \%$ CI $[0.773 ; 3.859], p=0.333)$. On the other hand, Hakansson and Kallen (2003) reported an association between cesarean section and increased hospitalization due to gastroenteritis. However, in this study, the incidence of gastroenteritis $(O R=1.162 ; 95 \%$ CI $[0.391 ; 2.715], p=0.142)$, urinary tract infection $(O R=1.346 ; 95 \%$ CI $[0.267 ; 2.959]$, $p=0.102)$, and tonsillitis ( $\mathrm{OR}=2.589 ; 95 \%$ CI $[-0,636 ; 1.121], p=0.242)$ showed no significant differences between children born by vaginal delivery and those born by cesarean section. In addition, the incidence of otitis among children born by cesarean section is not significantly different from that found among children born by vaginal delivery $(O R=0.028$; $95 \%$ CI $[-0.037 ; 1.094], p=0.400)$. The lack of significant differences between both groups may be explained by the evolution in child and pediatric healthcare, namely the regular prescription of vaccines to prevent diseases and the strict prescription of antibiotics.

In this study, no significant differences were found in the incidence of hypoglycemia $(O R$ $=1.022 ; 95 \%$ CI $[0.421 ; 1.604], p=0.997)$ between children born by elective cesarean section and those born by vaginal delivery. Although elective cesarean section, unlike vaginal delivery, requires women to fast before childbirth, this aspect does not seem to influence infants' development of hypoglycemia. In addition, no significant differences were found in the incidence of transient tachypnea $(O R$ $=1.051 ; 95 \%$ CI $[0.580 ; 1.660], p=0.284)$ between children born by elective cesarean section and those born by vaginal delivery. According to Siggers, Thymann, and Jensen (2008), infants born by vaginal delivery have higher glucocorticoid levels, which are associated with a greater maturation of the organs. However, this association was not found in this study concerning the reduction of the incidence of infant transient tachypnea. Not even the passage through the birth canal, which allows the fetus to expel the fluids and facilitates the adaptation to extra-uterine life, was enough to reduce the incidence of transient tachypnea.

Finally, this study found no statistically significant differences in the incidence of disease up to the age of two between children born by elective cesarean section and those born by vaginal delivery. The fact that this was a retrospective study is a limitation since a prospective study would provide additional data on laboratory specimens. Prospective studies should be conducted using data obtained from laboratory specimens from the mother's first trimester of pregnancy until the child's second year of life. The sample size was another limitation of the study because a larger sample would be more representative of the population. However, a larger sample would require more time for data collection, which would, in turn, compromise the timely implementation of the study.

\section{Conclusion}

No statistically significant differences were found in the incidence of diseases up to the age of two between children who were born by cesarean section and those born by vaginal delivery. Following the efforts of the World Health Organization to reduce cesarean sec- 
tion rates, this study suggests that arguments should not refer to the risk of disease among children until the age of two.

\section{References}

Administração Regional de Saúde do Norte. (2011). Relatório de atividades da ARS norte. 36-37.

Campos, I. (2008). Sistematização das indicações para cesariana. In D. Ayres-de-Campos, N. Montenegro, T. Rodrigues (Eds.), Protocolos de medicina materno-fetal (p. 194). Lisboa, Portugal: Lidel.

Cho, C., \& Norman, M. (2013). Cesarean section and development of the immune system in the offspring. American Journal of Obstetrics \& Gynaecology, 208(4), 249-250. doi:10.1016/j.ajog.2012.08.009

Decker, E., Hornef, M., \& Stockinger, S. (2011). Cesarean delivery is associated with celiac disease but not inflammatory bowel disease in children. Gut Microbes, 2(2), 91-98. doi:10.4161/gmic.2.2.15414

Hakansson, S., \& Kallen, K. (2003). Caesarean section increases the risk of hospital care in childhood for asthma and gastroenteritis. Clinical Experimental Allergy, 33(6), 757-764.

Huurre, A., Kalliomaki, M., \& Rautava, S. (2008). Mode of delivery: Effects on gut microbiota and humoral immunity. Neonatology, 93(4), 236-240. doi:10.1159/111102

Hyde, M., \& Moodi, N. (2012). The long-term effects of birth by caesarean section: The case for a randomised controlled trial. Early Human Development, 88(12), 943-949. doi:10.1016/j.earlhumdev.2012.09.006

Kaplan, J. L., Shi, H. N., \& Walker, W. A. (2011). The role of microbes in developmental immunologic programming. Pediatric Research, 69(6), 465-472. doi:10.1203/PDR.0b013e318217638a

Karpa, K., Paul, I., Leckie, J., Shung, S., Mauger, D., Fausnight, T., \& Carkacisalli, N. (2012). A retrospective chart review to identify perinatal factors associated with food allergies. Nutrition Journal, 11, 87. doi:10.1186/1475-2891-11-87

Martino, D. J., \& Prescott, S. L. (2010). Silent mysteries: Epigenetic paradigms could hold the key to conquering the epidemic of allergy and immune disease. Allergy, 65(1), 7-15. doi:10.1111/j.13989995.2009.02186.x

Neu, J., \& Rushing, J. (2011). Cesarean versus vaginal delivery: Long-term infant outcomes and the hygiene hypothesis. Clinical Perinatology, 38(2), 321331. doi:10.1016/j.clp.2011.03.008

Ngoc, P. Ly., Begońa Ruiz-Pérez, Andrew, B. O., Arthur, O, T., Augusto A, L., Catherine, L.,...Juan C. C. (2006). Mode of delivery and cord blood cytokines: a birth cohort study. Clinical and Molecular Allergy, 4(13), 1-11. doi.org/10.1186/1476-79614-13

Pistiner, M., Gold, D. R., \& Abdulkerim, H. (2008). Birth by caesarean section, allergic rhinitis, and allergic sensitization among children with a parental history of atopy. Journal of Allergy and Clinical Immunology, 122(2), 274-279. doi:10.1016/j. jaci.2008.05.007

Roduit, C., Scholtens, S., \& de Jongste, J. C. (2009). Asthma at 8 years of age in children born by caesarean section. Thorax, 64(2), 64-113. doi:10.1136/ thx.2008.100875

Salam, M., Margolis, H., McConnell, R., McGregor, J., Avol, E., \& Gilliland, F. (2006). Mode of delivery is associated with asthma and allergy occurrences in children. Annals of Epidemiology, 16(5), 341-346. doi:10.1016/j.annepidem.2005.06.054

Siggers, R. H, Thymann, T., \& Jensen, B. B. (2008). Elective cesarean delivery affects gut maturation and delays microbial colonization but does not increase necrotizing enterocolitis in preterm pigs. American Journal Physiology, Regulation, Integrative and Comparative Physiology, 294(3), 929-938. doi:10.1152/ajpregu.00705.2007

Strachan, D. P. (1989). Hay fever, hygiene, and household size. British Medical Journal, 299(6710), 1259-1260. doi:10.1136/bmj.299.6710.1259

Wang, L., Arsham, A., Southerland, J., Wang, K., Anderson, J., \& Stevens, M. (2013). Cesarean section and the risk of overweight in grade 6 children. European Journal Pediatrics, 172(10), 1341-1347. doi: 10.1007/s00431-013-2043-2

World Health Organization. (2015). WHO statement on cesarean section rates. Geneva, Switzerland: Author. 